This item was submitted to Loughborough's Research Repository by the author.

Items in Figshare are protected by copyright, with all rights reserved, unless otherwise indicated.

\title{
A 'Strategy-as-Practice' exploration of lean construction strategizing
}

PLEASE CITE THE PUBLISHED VERSION

http://dx.doi.org/10.1080/09613218.2012.655925

PUBLISHER

(C) Taylor \& Francis (Routledge)

VERSION

AM (Accepted Manuscript)

LICENCE

CC BY-NC-ND 4.0

REPOSITORY RECORD

Sage, Daniel J., Andrew R.J. Dainty, and Naomi Brookes. 2019. "A 'strategy-as-practice' Exploration of Lean Construction Strategizing”. figshare. https://hdl.handle.net/2134/11112. 
This item was submitted to Loughborough's Institutional Repository (https://dspace.lboro.ac.uk/) by the author and is made available under the following Creative Commons Licence conditions.

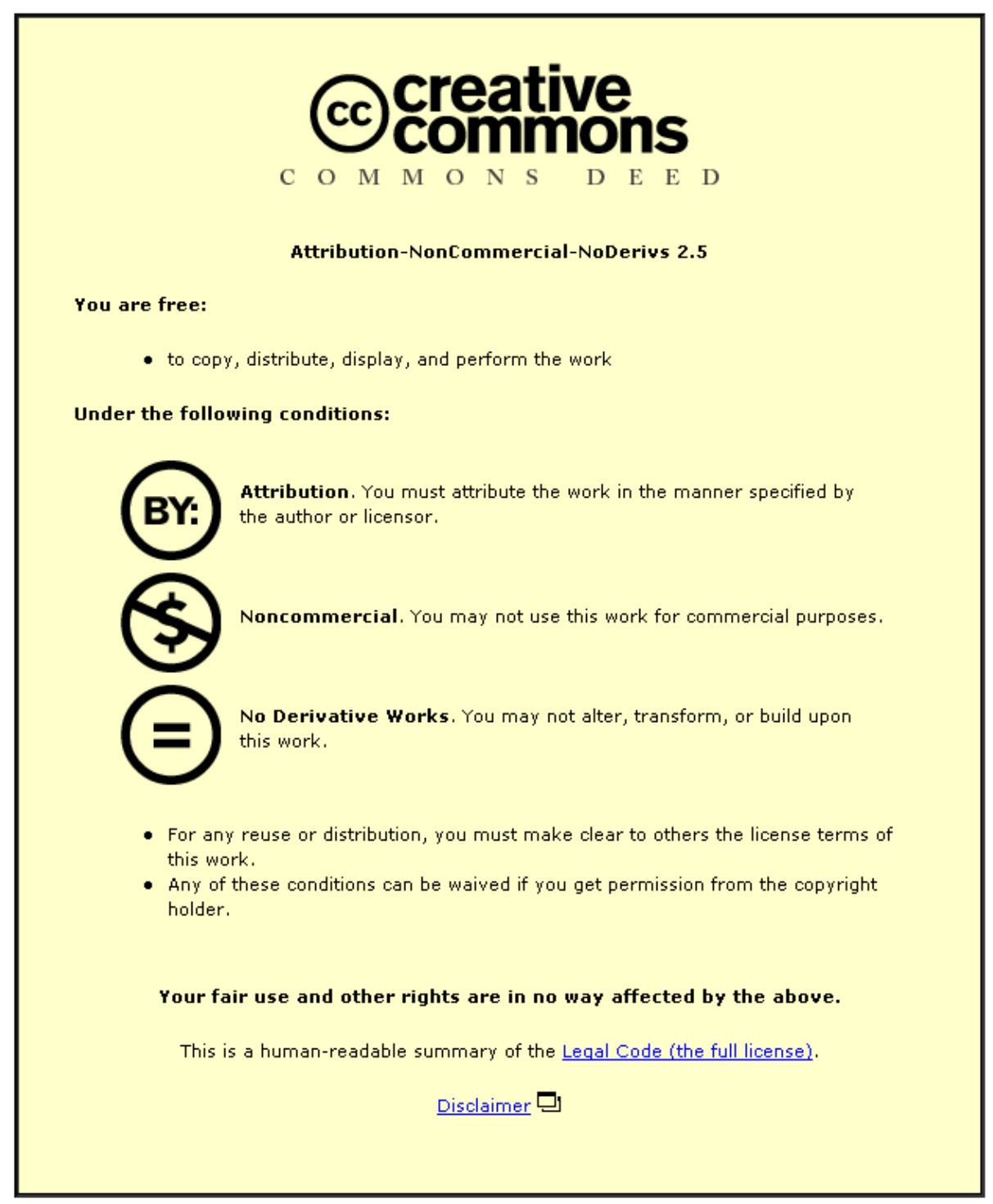

For the full text of this licence, please go to: http://creativecommons.org/licenses/by-nc-nd/2.5/ 
A 'Strategy as Practice' Exploration of Lean Construction Strategizing

\title{
Daniel Sage (corresponding author)
}

Department of Civil and Building Engineering

Loughborough University

Loughborough

Leicestershire

LE11 3TU

d.j.sage@lboro.ac.uk

\author{
Andrew Dainty \\ Department of Civil and Building Engineering \\ Loughborough University \\ Loughborough \\ Leicestershire \\ LE11 3TU
}

a.r.j.dainty@lboro.ac.uk 


\author{
Naomi Brookes \\ Department of Civil and Building Engineering \\ Loughborough University \\ Loughborough \\ Leicestershire \\ LE11 3TU \\ n.j.brookes@lboro.ac.uk
}

Abstract

A growing body of work emerging from the management and organizational studies literature is the 'Strategy-as-Practice' (SaP) perspective, which focuses on the ways in which strategy is enacted or 'done' within organizational settings. In this paper we use this perspective to examine the diffusion of lean construction. In recent years, lean construction has grown in prominence to become one of the primary performative improvement recipes for the sector. However, rather than lean providing a stable strategy around which more collaborative, intelligent and efficient project-based organizations develop, 
this research reveals how it transforms during its journey with unintended consequences for organizations. Ethnographic study, informed by SaP, demonstrates how a lean strategy and its effects on organizational practice and culture cannot be understood separate from its material and embodied practices and its power effects. As well as contributing to the empirical examination of lean construction practice, this paper opens up new trajectories for research into strategizing within construction which are orthogonal to celebratory or critical positions and provides researchers with ways of exploring lived practices and spaces where strategizing takes place.

Keywords: Construction Strategy, Strategy-as-Practice, Lean Construction, Power

Number of Words: $\underline{\mathbf{5 6 8 8}}$ (excl. abstract, acknowledgement and bibliography)

\section{Introduction}

Over the last thirty years the United Kingdom's construction industry has become subject to various strategic improvement recipes, from Sir John Egan's Rethinking Construction (1998) report to Never Waste a Good Crisis (Wosthenholme, 2009). A plethora of project, programme and portfolio 
management workshops, qualifications and certifications within the sector have been identified as 'best practice' - the modus operandi of improved organizational development and corporate value (Green and May, 2003; 2005; Green et al., 2008; Kao et al. 2009; Leiringer et al., 2009; Ness, 2010). One such approach is Lean Construction, as advocated in Egan (1998). Lean has gained widespread popularity in the construction sector (e.g. Alarcón, 1997 Ballard and Howell, 1994; 2003; Garrett and Lee, 2011; Howell and Ballard, 1999; Paez et al. 2005). Adopting lean construction has been reported to yield significant performance benefits.

Increasingly however various studies of the construction industry have shown how strategies, such as Lean Construction, are more open to mutation than often recognized, and indeed may be prefigured for local transformation (Green and May, 2005). Drawing on a Foucauldian perspective for example, enables these strategies to be viewed as dynamic discourses that both legitimize and conceal a complex, mutable, milieu of socialized interests, ideologies and power relations (Green and May, 2005; Green, 2006; Ness, 2010). Whilst various studies have shown how construction strategies are translated (and transformed) across reports and elite actors at the level of the firms or sector (e.g. Green and May, 2005; Green et al. 2008; Kao et al. 2009; Leiringer et al. 2009; Ness, 2010) and around individual actors on building sites (Applebaum, 1982; Bresnen, 2007; 2009; Fletcher and Watson; Green, 2006; Styhre, 2006; Watts, 2007), these 
studies only rather indirectly examine the meso-level events, practices, objects and people (such as training meetings, change initiative posters, improved planning tools, business improvements managers, local champions) that bridge these two spaces in the context of construction. In this paper we argue that a focus on this level of strategizing is required because it provides a vital understanding of how strategies such as those pursued in lean construction are translated (and transformed) between the level of firms and organizations and the everyday practices on building sites.

For this reason we will adopt a 'Strategy-as-Practice' (SaP) derived approach which offers a useful conceptual framework to connect macro and micro practices of strategizing (Jarzabkowski et al. 2007). In doing so we draw attention to the way strategies are not only extended, disseminated or implemented, but also appropriated, translated and transformed by specific people, artifacts and events, often in unintentional ways. The aim of this paper is to explore the implementation of lean construction through a SaP perspective, thus contributing a greater understanding of the way strategies such as lean within construction can become transformed on their promulgation, and with what effects for an organization. The findings should have resonances for both those with a general interest in how strategy is enacted within construction organizations, as well as those interested in the socialized power effects of lean construction specifically. 
The remainder of the paper is organized into three sections. The first section briefly introduces how a SaP perspective can assist in developing a meso-level approach to understand construction strategizing, including the case of lean construction. The next section introduces the research approach and case study context. The empirical discussion of Lean has four sub-sections that explore four contextual settings where lean strategizing has been translated within construction: (i) government policy and academic research, (ii) boardrooms; (iii) training rooms and (iv) construction sites. The paper concludes by describing what a meso-level approach, informed by SaP, can provide for understanding construction strategizing.

\section{The Strategy-as-Practice Perspective}

The SaP approach defines strategy as something that people do rather than something that a firm possesses (Whittington, 2006). SaP encourages us to ask "who strategists are, what they do and why and how that is consequential in socially accomplishing strategic activity" (Jarzabkowski et al. 2007: 19). SaP is capable of informing a meso-level investigation into strategizing in construction, and beyond, because it provides a set of approaches, concepts and methodologies that seek to understand how strategies are translated (and transformed) beyond senior managers and policy documents into everyday contexts. 
SaP research provides a meso-level of analysis by repositioning macro-level, sometimes abstract, strategic concerns related to the firm (e.g. efficiency, standardization) alongside the everyday lived practices of practitioners (cf. Johnson et al. 2003). SaP, as with other practice-based research (Bresnen, 2009), is particularly concerned with questions of power; who can implement a strategy; what interests does a strategy serve; who can strategize; how can you enroll others in your strategy; how is a strategy resisted or transformed. These questions will conceptually guide the empirical discussion of this study, as they help prompt an analysis of how strategizing is an on-going social accomplishment within organizations, involving particular interests, ideologies, contexts and relations of power.

In developing an SaP approach three objects of analysis are vitally important: (i) practitioners ("those doing strategy"), (ii) practices ("the social, material and symbolic tools of strategy") and (iii) praxis ("the flow of activity in which strategy is accomplished") (Jarzabkowski and Spee, 2009: 70; see also Jarzabkowski et al. 2007; Whittington, 2006). SaP research has, thus far, included studies of strategizing in contexts as diverse as universities (Jarzabkowski, 2003); engineering construction (Laine and Vaara, 2007) and airlines (Vaara et al. 2004). These studies have drawn upon various conceptual and methodological sources, including discourse analysis, sense-making, ethno-methodology and structuration (Jarzabkowski et al. 2007), to understand strategizing as a complex 
set of socialized practices distributed across, and beyond, an organization rather than a rational object that senior managers apply to firms, units, projects and employees. Moreover, in contrast to many perspectives on strategizing in construction (e.g. Ballard and Howell, 1994; 2003; Egan, 1998; Koskela, 1992), SaP demonstrates that as strategies spread across different contexts, for instance from universities to government to industry, they will tend towards disintegration and multiplication rather than integration and alignment; this is because they travel across different settings, or "discourses", and are consequently misunderstood, albeit sometimes productively (Seidl, 2007: 214). This presents an important consideration for this study: the practical relevance of the concepts developed in this paper are themselves subject to transformation between academic and industrial discourses. Following Seidl (2007), we can perhaps only set out to foster productive (mis)understandings about the potential for strategizing in construction organizations. The next section will introduce our case study and explain how SaP approaches inform the research methodology mobilized in this paper.

\section{Research Approach and Context}

SaP research demands a careful consideration of the research process if the situated and emergent nature of strategizing is to be comprehended (cf. Jarzabkowski et al. 2007: 22). Rasche and Chia (2009) suggest that SaP perspectives should juxtapose traditional research methods (e.g. structured interviews and questionnaires) and documentary analysis with ethnographic 
observation. Unlike interviews, observations enable researchers to understand how everyday practices (such as moving, gesturing, facial expression etc.) and dynamic material interactions (with PowerPoint, Desks, Forms, Scorecards, Plans etc.) shape the craft of strategy.

The data within this paper was gathered over a period of 12 months (during 2008-9) within a wider two year research project addressing the sociologies of construction project management. The research presented in this paper is concerned with one of the companies, hereafter named CONCO, involved in this wider research project. During the research project CONCO was implementing a lean construction improvement strategy. Access to CONCO was secured through one of the authors of this paper whom has collaborated with the organization across various research projects mostly related to human resource management. Data was collected from CONCO across five visits to the company's headquarters and visits to six project sites (each lasting approximately one week) with followup visits. The study organization is a privately owned general construction contractor operating across the United Kingdom. The data gathered in this paper includes observations, documents and semi-structured interviews with various project practitioners and analysis of documentary material. Observational data was recorded through field notes made by the lead author of this paper. Documents gathered included corporate reports, strategy pamphlets, training documents, project plans and site meeting minutes. Interviewees were asked a 
variety of questions concerning their role in CONCO, their experiences of their current project and more general questions about the changes within CONCO including the lean improvement programme. Interviews were recorded and were later transcribed.

The insights and ideas developed in this paper were developed in collaboration with the practitioners involved both in informal conversations and in a series of bi-annual collaborative steering- group meetings. In these meetings practitioners from the study organization were invited to reflect upon research findings both prior to, during and post fieldwork. This collaborative research methodology is important to SaP approaches as it challenges the assumption that researchers should or can develop insights about rather than with research subjects, instead practitioners and researchers worked together to develop and reflect upon their practices as they emerge (cf. Chan and Räisänen, 2009; Ewenstein and Whyte, 2007; Van de Ven, 2007). This technique also enables greater awareness, though not alleviation, of (mis)translation and (mis)understanding between academiaindustry discourse, as described by Seidl (2007).

Following a SaP-orientated approach through an empirical case-study allowed us to trace lean strategies from their origins within various government sponsored reports, initiatives and institutions, and into a specific construction company via presentations, training meetings and eventually site work. Following the advice 
of Rasche and Chia (2009) we have deliberately chosen in this paper to focus primarily on strategic practices that we can capture through direct ethnographic observations. As a result, whilst in the next section we provide an initial overview of the emergence of lean in construction as a series of "top-down" initiatives, this story is only given to indicate the intention, and debates, around lean, and must not be mistaken for the actual "strategy in action". Strategies can, and are, influenced by a range of spatially and temporally distant actors from CEOs to government ministers and reports which can influence practices "here and now" - equipping actors with resources to enact, understand and transform their application.

\section{Lean Strategizing: The Case of CONCO}

\section{The Rise of Lean Strategies in Construction}

In order to understand lean strategizing within CONCO, it is important to understand the evolution of lean thinking in the wider construction sector. Over the last decade construction companies have increasingly looked to lean thinking as a means to improve project cost and time predictability, build quality, supply chain relationships and flexibility so as to generate greater competitive advantage and stronger client relationships. Lean construction first emerged in the construction management (CM) research community in the early 1990s, towards the end of a period of Western interest in Japanese manufacturing 
techniques (Ballard and Howell, 1994; Koskela, 1992), particularly the Toyota Production System (Liker, 2004). The International Group for Lean Construction was founded in 1993; holding its first annual meeting in Finland in the same year. The Lean Construction Institute (LCI) was subsequently founded in 1997, since 2004 the LCl has published the Lean Construction Journal inviting contributions of lean thinking from academics and practitioners. In the UK the translation of theories of lean construction into practice was in no small part due to the way that influential government-backed reports and client groups promoted lean thinking within construction, for example Sir John Egan's Construction Task Force Rethinking Construction report in UK construction (Egan, 1998).

Constructing Excellence (CE) founded and funded by the UK government in the wake of the Latham (1994) and Egan (1998) reports on the construction industry, provides an important platform to disseminate 'best practice' in the UK via forums, workshops and newsletters to practitioners. Lean thinking provides just one of these best practice strategic formulas. $\mathrm{CE}$, and its initiatives including lean, were designed to offer solutions to an industry the Latham (1994) report described as ineffective, fragmented and adversarial, criticisms which pervade the construction management literature as inhibitors of performance improvement. The CE website summarizes lean construction in six principles which intersect with many other espoused CE themes; including 'leadership/people', 'value', 'integration/collaboration' and 'sustainability' (cf. Constructing Excellence, 2010). Amongst various lean-related activities, CE 
promotes lean through the Construction Lean Improvement Programme (CLIP) offered by the Building Research Establishment (BRE) and supported by the Department of Business, Innovation and Skills. CLIP began in 2003 directly in response to the Rethinking Construction report (BRE, 2010). CLIP does not offer generalized training but rather a sustained series of tailored engagement activities, from reviews to specialized training, by a team of lean experts in a business to enable that business to bring their processes in-line with lean principles (CLIP, 2007). The general applicability of lean principles is emphasized in CLIP who suggest that it is equally useful to guide the strategy of a single subcontractor or across a cluster of companies (CLIP, 2005).

Green and May (2005) have suggested that 'lean construction manifests in one of three modes:

Mode 1: Lean as waste elimination (e.g. JIT);

Mode 2: Industrial partnering (e.g. empowerment of supply chain, knowledge sharing);

Mode 3: Wider structural change (innovative use of prefabrication, IT systems, inter-industry relationships).

Green and May (2005) suggest mode 3 is less common as it often entails the reorganization of contractual boundaries and a much greater emphasis on research and design practices. These are difficult paths to implement within the 
construction industry, where the short-term pressures of winning work at the lowest cost usually win out over the long-term development of the industry (cf. Ness, 2010). Notwithstanding these difficulties, this schema provides a useful framework to map the range of different understandings of lean strategy encountered within the organization studied and is mobilized below.

\section{Lean Strategizing in The Upper Echelons of CONCO}

It is significant for our research that the CEO of the general contractor we studied was a strong advocate of lean thinking. Against this context the CEO of the company sought to encourage lean thinking within the company he led from 2006. He was familiar with various books on Lean thinking including Womack and Jones' seminal titles on the subject (Womack and Jones, 1996). The implementation of lean construction in CONCO was set against a backdrop of ongoing organizational changes that took place during the 1990s in an effort to increase the competitiveness of the organization. CONCO had begun to develop a lean strategy following consultation with their supply chain. As well as various process measures, this also included a set of values which supported the lean vision of the firm. These included a focus on innovation, customer focus and teamwork. These were supported by lean principles amalgamated into the 'CONCO Values' largely adapted from the 14 lean strategies found in the "Toyota Way" or Toyota Production System (TPS) (as outlined in Liker, 2004). CONCO's 
senior management team adopted some of these verbatim from the TPS and adapted others to their own operating context to formulate the 'CONCO values'. Through a comparative analysis, we can see how the lean values of Constructing Excellence and the Toyota Production System have been translated, and transformed, by CONCO. Firstly, there was a clear emphasis on removing some of vernacular of a linear production line from the principles. Secondly, there appeared to be more of an emphasis on control and individual responsibility rather than empowerment and teamwork. Thirdly, the language seemed to steer away from some more specific, and longer term commitments for the organization. CONCO's articulation of lean principles were broadly in keeping with modes 1 and 2 as defined by Green and May (2005). Notably CONCO seemed to reject the kind of increased R\&D expenditure, training and interindustry relationships (e.g. training and personnel development) which would indicate mode 3.

The CEO's strategic intention for Lean within CONCO was enacted through a range of mechanisms including the appointment lean champions; lean pilot projects; an organization-wide management development programme; and a range of new standardized documentation (including visual controls). By paying attention to the way Lean was translated across specific material practices and sites (books, individuals reports), we can see how it was transformed as it moved from one organizational setting, or discourse (i.e. Japanese production to British construction), to another (cf. Seidl, 2007: 207) At this point in our analysis it 
appears that lean construction has been reified in CONCO through a network of aligned objects, events, people and practices as the strategic discourse. However, as Seidl (2007) proposes we can only adequately understand whether a strategy has been successfully aligned with managerial practice within organization by paying attention to all the settings in which it is mobilized. Using a SaP perspective it is further possible to trace the mobilization and transformation of lean strategies within CONCO from those envisaged by the CEO through the levels of management to the point at which the strategies were enacted at sitelevel.

\section{Lean Strategizing in Training Sessions}

Training Sessions began with the rhetoric of post-bureaucratic organizations and lean strategizing but tended to shift quickly to mode 1 and mode 2 considerations of lean thinking. The structure of the sessions reinforced this movement with the senior manager presenting in a theatrical style to a largely passive audience of more junior managers. For example, one senior manager stated: "I can recognize [a good project], and you can, trick is how to recognize one early on?". Suggestions varied from those relating to emotional states within the project (e.g. "a good atmosphere") to those concerned with operational efficiency (e.g. "good co-ordination" and "everyone knowing what they are doing"). The latter ideas tended to be picked out and followed-up by the senior managers. Senior managers ignored other potential articulations of lean 
strategizing (e.g. concerns about programmes being undertaken against too tight time objectives, the failure to recruit good managers, chasing programmes that were outside CONCO's capabilities.) The line managers involved in training sessions usually remained silent when asked to reflect on particular points in small group at tables: the senior managers slowly walked around the room monitoring progress and asking the line managers to report back separately in turn.

This structure and process of the trainings sessions seemed to be at odds with the ideas of open communication, collaboration and interactive learning as emphasized at the start of the session and articulated by CONCO's CEO as being fundamental to lean strategies. Notably the strategic decisions-making process itself, including the individuals behind the lean approach, was never up for discussion. This passivity served senior managers well to establish the boundaries of the discussion and to propagate their interpretation of lean strategizing. Here we might start to see how this training session became a place to reify extant power relations. Only the senior managers felt able to speak collectively about "us", "we" and "our" (cf. Samra-Fredericks, 2005) and able to interrupt others in the room. The line managers spoke largely in relation to their individual experiences (use of the "I"); affirming a sense that they are defined and grounded subjects, while the senior manager spoke from a more disembodied voice of and for the organization or the industry. 
The outcome of the session were a set of action plans related to improving identified lean thinking in the spaces beyond the meeting, which would be checked at the next session. The production of these action plans, concerning more regular meeting attendance on-site, for example, appeared enough to evidence 'continuous improvement'.

The silence and passivity of participants should not be viewed as acquiescence or agreement to the lean strategizing by the line-manager participants. A more critical interpretation of the day was offered by one senior line manager nearing retirement age, who privately uttered to one of the authors: "this is all good for young guys who want promotion, it is irrelevant for me; I know what I am doing". This alternative explanation of the value of the lean strategy perhaps reveals that the silence of line managers, may speak more of cynicism. While cynicism has been explained by some as passive acceptance (Fleming and Spicer, 2003), it may also suggest that the currency of lean (and perhaps other strategies) holds more value as an identity marker in headquarters than on-site as a practical tool. Using a SaP perspective to view the training sessions, we can begin to see how the orchestration of existing power relations to drive the senior managers' lean interpretation and the passive acceptance of these by lean managers transformed CONCO's lean strategizing. Other actors than CONCO's CEO, could be seen to shaping the way that CONCO's lean strategy was developing. This transformation process continued with the propagation of lean strategizing through CONCO and it is to the building site that our examination will now turn. 


\section{Lean Strategizing on Site}

A SaP perspective emphasizes the need to examine embodied practices and material practices in order to fully understand the eventualities of the strategizing process. Across the CONCO sites we visited during 2008 and 2009 we found evidence of the diffusion of CONCO lean values, principles and processes. The lean process improvement manager and team had visited many of the sites before undertaking our research. They had given seminars on various improvement processes, including forward planning, visual aids and collaborative sub-contractor meetings. CONCO values had been printed on business cards and numerous posters of the vision and more detailed principles were found on the walls of many site cabins. In addition, many of the site meeting rooms contained extensive progress charts and plans, providing access to potential problems for different actors. However, it was notable that whiteboard action lists remained empty or were used purely to notify employees of meetings. When asked how useful the posters or cards were, most employees seemed quite surprised that any attention had been drawn to them at all. The progress charts in the meeting rooms were often ignored in progress meetings, instead actors would draw upon their own notes or experiences of what is happening or not on site. Some may view this lack of attention to the materiality of strategies by employees as a contradiction of recent calls to attend to the materiality of strategizing in SaP (Rasche and Chia, 2009; Jarzabkowski and Spee, 2009). However, it also indicates vindicates Latour's (2005) proposal that material objects can no more 
bring about social change by themselves than people can. Indeed various studies of construction have demonstrated that objects do not upon people or vice versa but rather agency is located between them, this is no less true of lean construction than 3D-CAD (Harty, 2008) or construction project management (Sage et al. 2010).

At a site-level, CONCO's lean strategy was most often viewed in terms of the promotion of collaborative planning meetings with sub-contractors intended as problem-solving and learning forums. These aim of these meetings as espoused by CONCO's lean improvement managers was to encourage the empowerment of lower level employees as part of the project strategy. A project manager on a different site in the English Midlands explained the importance of these meetings:

If you don't do that collaborative planning session people don't understand and if they don't understand they don't pay any regard to other members of the supply chain and other members of the team.

Working under this particular project manager were three site managers who were responsible for delivering particular packages of work through the management of sub-contractors. When site-managers were directly asked about 
the CONCO Values they described it as beneficial to their work, both in its content and the way it was implemented:

They tutored us on it and made us aware of it and explained to us not just this is what you are doing but this is why we want to do it, this is the benefits of it. I think that is fundamental. Far too many times we have had policies and procedures updated, this is what you will do, well why are we doing it, I don't know. I think if you understand why the business wants you to do something, what the benefits are, I think it makes it much easier to carry it out and implement it (CONCO site manager \#1).

They also gave evidence how collaborative meetings did emphasize teamwork and planning between themselves and sub-contractors:

I think at first they (subcontractors) thought it was the opportunity to tell us how long it was going to take them and if we said no that's not true they would use, well this is supposed to be collaborative, as an excuse. They didn't really understand where everyone was coming from at first, and it did take a couple of months for them to understand what collaborative meant was not giving them the opportunity to tell us how long they wanted to do it. It was actually the process of getting them to 
work together to deliver what they signed up to on our target programme and to challenge it. That was the biggest challenge. It has been a bumpy ride and the meetings do occasionally get a bit emotional a bit heated but it is bound to, these guys are under a lot of pressure. They all realize that if I let him down I am only going to get shafted for it. (CONCO Site manager \#1)

However, in other cases substantive disconnect was observed from the CONCO Values. Far from being an egalitarian and participatory discussion between all involved, meetings morphed into more traditional progress reviews reinforcing contractor/sub-contractor power relations. In one meeting with the external envelope sub-contractors, the site manager asked each sub-contractor in turn to describe their work achieved. These accounts were then compared to the planned work from the week before. The difference between the planned and the achieved work was then noted by an assistant site manager in a progress report. If there was a large discrepancy between planned and achieved work the site manager would ask what the problem was and then propose a solution based on the site managers own interpretation of the problems on site that week. Frequently the solution would involve demands by the site manager for greater productivity or the provision of over-time at the weekend. Many of the problems were traced back to access issues, either due to the difficulty of making scaffolding changes or the obstruction caused by delayed work in another part of 
the site. Once these problems had been discussed each sub-contractor would then complete a new schedule of planned work for the next week. Notably only the scaffold sub-contractor was present throughout the meeting; other subcontractors would leave the meeting early once they had discussed their progress. Significantly many of the sub-contractors were represented by different individuals from week to week in the collaborative meetings - not surprisingly therefore the commitments made by the representative for the previous week were contested. A different site manager on the same project provides similar evidence of the shift from a strategy of collaboration to confrontation when recalling a collaborative meeting:

I gave them a bit of a tongue lashing this morning, what I call good old fashioned, went through the areas and said listen you need to come more prepared. I want you to pick off the lean board, the lean board is identical to the completion programme, and there can't be anything different to that.

[we need] to get them to look at what they are doing and think for themselves. I think it has always been with sub contractors I find that we end up managing them when they should manage themselves.. he should come to you and say this week I have looked at the programme, because I don't think they all look at the programme to be fair. (CONCO site manager \#2) 
These models of work appear scarcely radically different to traditional project control techniques. By examining the actuality of embodied managerial processes using a SaP perspective, it was revealed that 'Lean construction' had seemingly been translated on many sites in CONCO into a means of improving resource co-ordination, more intensive surveillance, and more productivity pressure, driven by a growing distrust for sub-contractors. The different interests of actors had not been reconciled at all in a more open, empowered, trusting culture instead they had been put to the test by a more rigorous monitoring system that sought to publicly "name and shame" those who did not perform. The situations described here appear a long way from the empowered supply chain, knowledge sharing, learning organization associated with CLIP, or even the CEO's view of lean as a cultural change towards openness, honesty and teamwork. In these meetings notions of 'collaboration' and 'lean' appear to sustain and legitimatize the weekly collaborative meetings as a form of surveillance more similar in form, if not content, to the lean training session at CONCO headquarters.

\section{Discussion and Concluding Comments}

The aim of the paper was to use a SaP perspective to understand the enactment of lean strategizing in the construction industry. SaP provided a mechanism to explore the 'meso-level' hinterland of lean strategizing between the intentions 
for lean of the CEO of CONCO, and government initiatives such as CLIP, and the actuality of site-level managerial practice. Using an SaP derived perspective in the CONCO case, we can see how a conceptualization of lean at an industry level as a 'mode 3 ' encapsulation of wide ranging change was transformed by CONCO's CEO into a more focused concentration of mode 1 and mode 2 lean strategizing. As Lean was dispersed through training events it was further modified by senior managers and line managers to its final enactment by sitemanagers as a planning review meeting that the strengthened power relations of the general contractor over sub-contractors. In SaP terms, all of these actors played a substantive role as practitioners in the praxis of strategizing lean within CONCO. SaP provided a useful framework to capture the process of lean strategizing within CONCO and has thus demonstrated the potential for equal utility to understand the effects of lean strategizing in other construction contexts, particularly with regard to understand how strategies may help reify, rather than displace, preexisting power relations within organizational settings. Of course, this state of affairs may not be undesirable for individual actors to get work done or improve their status within the organization; however it certainly seems a significant transformation of the rhetoric of cultural change ('team working', 'collaboration' etc) within Lean Construction (e.g. Ballard and Howell, 2003). 
Whilst we could take the view Lean Construction is simply resisted in our case study rather than transformed; in other words, lean made no difference to CONCO, this view underplays the transformative value that Lean played in the different settings discussed. For instance, lean helped justify a new way in which sub-contractors monitored each other rather than being solely monitored by the general contractor. Lean also enabled more contact between senior managers and young line managers whom can employ the language of lean as a new vehicle for career progression. Whilst such translations and transformations appear at odds with the established version of lean (e.g. Ballard and Howell, 2003), they also do not merely indicate the failure of lean either (Green, 1999a, 1999b), but rather the multiplication of lean into new discourses and settings with real consequences for the direction of CONCO projects and CONCO.

This paper yields interesting insights for those who are further seeking to enact (or research the enactment) of lean construction. It would be tempting to conclude that this paper's primary contribution is to provide an empirical exemplification of Green and May ‘s (2005: 510) prediction that :

The likeliest outcome is that managers give lip-service to the language of lean, whilst persisting with established practices and routines. A widespread risk aversion amongst middle managers, coupled with an institutionalized allegiance to short-term cost reduction policies, renders comprehensive change unlikely. 
Certainly, in the case of CONCO, the 'lean' strategy found at the site-level was severely reduced in coverage and in many ways contradictory to the 'mode 3 ' exhortations and expectations of lean thinking encountered in industry-level embodiments of 'best-practice.' However the SaP informed tracing of the social journey by which this transformation took place allows for speculation on different scenarios. What if the senior managers had employed a participative structure for the site-training sessions that encouraged participation and holistic thinking (even perhaps by asking that subcontractors ensured consistency in whom attended)? What if the need for collaboration that had captivated Site Manager \#1 had spread throughout CONCO? SaP informed narratives, of the type developed in the body of this paper, can provoke practitioners to envisage alternative trajectories for lean strategizing within CONCO. Whilst we must recognize that the translation of any concept (whether Lean Construction or indeed SaP) from academia to industry is always subject to misunderstanding, even if productive (Seidl, 2007), our experience in the steering groups throughout our research revealed that practitioners are eager for reflexive research approaches, such as SaP, that can help understand how strategic (mis)understanding, (mis)translation and transformation plays a role in the direction and survival of their own organizations.

Further SaP research in construction strategizing could start to examine not only how different strategies are translated and transformed judged against an 
original strategic intent, but what performative effects this may have within an organization, for example in winning work, finishing projects on time and to cost and retaining staff. One possible method could be to compare project performance where there is a high degree of cohesion with corporate strategic intent and those with increased diffusion. It might be assumed that those projects with a high degree of strategic alignment are most successful in performative terms; however as many other practice-studies of construction have shown local adaptation to top-down initiatives can equally prove advantageous, or necessary, in certain settings (Bresnen, 2009; Harty, 2008; Sage et al. 2010). By addressing such questions, SaP studies of construction strategizing can help equip reflective practitioners with an awareness of the plethora of strategic trajectories, (along with a keen awareness of the role that all practitioners play in strategic praxis) which would provide individuals at the start of a strategic implementation within an organization with valuable insights to insure that the final articulations of strategy, and their performance outcomes, more closely resembled the beneficial states they wishes to obtain.

\section{Acknowledgements}

We would like to thank CONCO for allowing us to undertake this research and those who took part in this study. This paper builds upon a paper first presented at the Critical Management Studies Conference, University of Warwick, 2009 and later re-developed for a presentation at Research Institute for the Built 
Environment at the University of Reading. We would also like to thank the three anonymous referees whose comments have helped us strengthen the focus and contribution of this paper.

\section{References}

Alarcon, L. (ed.) (1997) Lean Construction, Taylor and Francis: London.

Applebaum, H., A. (1982). Construction Management: Traditional versus Bureaucratic Methods, Anthropological Quarterly 55(4): 224-234.

Ballard, G. and Howell, G. (1994) Implementing Lean Construction: Stabilizing Work Flow, Proceedings of the 2nd Annual Meeting of the International Group for Lean Construction, Santiago, Chile.

Ballard, G., and Howell, G. (2003). Lean Project Management, Building Research and Information. 31(2), 119-133. 
BRE (2010) Construction Lean Improvement Programme.

http://www.bre.co.uk/page.jsp?id=355

Accessed 1/7/20.

Bresnen, M. (2007) Deconstructing partnering in project-based organisation:

Seven pillars, seven paradoxes and seven deadly sins. International Journal of Managing Projects in Business 25(4), 365-374.

Bresen, M. (2009). Living the dream? Understanding partnering as emergent practice. Construction Management and Economics 27(9): 923-933.

Bresnen, M. and Harty, C. (2010) Objects, knowledge sharing and knowledgetransformation in projects. Construction Management and Economics, 28(6), 549-555.

Chan, P, W. and Räisänen, C. (2009) Editorial: informality and emergence in construction, Construction Management and Economics, 27(10), 907-912.

CLIP (2005) Construction Lean Improvement Programme.

http://www.constructingexcellence.org.uk/resources/themes/clip/clip.jsp Acessed 12/7/10. 
CLIP (2007) What is CLIP? http://www.bre.co.uk/page.jsp?id=355

Accessed 12/7/10.

Constructing Excellence (2010) Constructing Excellence,

http://www.constructingexcellence.org.uk, Accessed 12/7/10.

Egan, J. (1998) Rethinking Construction, Construction Task Force Report for

Department of the Environment, Transport and the Regions, HMSO: London.

Ewenstein, B. and Whyte, J. (2007) Beyond Words: Aesthetic Knowledge and Knowing in Organizations. Organization Studies, 28(5), 689-708.

Fleming, P. and Spicer, A. (2003) Working at a Cynical Distance: Implication for

Power, Subjectivity and Resistance. Organization 10 (1), 157-179.

Fletcher, D. and Watson, T. (2007) Voice, Silence and the Business of Construction: Loud and Quiet Voices in the Construction of Personal, Organizational and Social Realities. Organization, 14 (2), pp.155-174. 
Garrett, D, F. and Lee, J. (2011) Lean Construction Submittal Process - A Case Study, Construction Management and Economics, 23(1), 84-93.

Green, S.D. (1999a) The Missing Arguments of Lean Construction. Construction Management_and Economics, 17(2), 133-137.

Green, S.D. (1999b) The dark side of lean construction: Exploitation and ideology, 7th Annual Conference of the International Group for Lean Construction (IGLC-7), Berkeley, California, USA,

Green, S.D. (2006) The management of projects in the construction industry: context, discourse and self-identity, in D. Hodgson and S. Cicmil (eds) Making Projects Critical, Palgrave Macmillan, Basingstoke, pp. 232-51.

Green, S. and May, S, C. (2003) Re-engineering construction: going against the grain. Building Research and Information, 31(2), 97-106.

Green, S. and May, S, C. (2005) Lean construction: arenas of enactment, models of diffusion and the meaning of 'leanness'. Building Research and Information, 33(6), 498-511. 
Green, S. and Schweber, L. (2008) Forum Theorizing in the context of professional practice: the case for middle-range theories. Building Research and Information, 33(6), 649-654.

Green, S. Harty, C. Elmualim, A, A. Larsen, G, D. and Kao, C, C. (2008) On the discourse of construction competitiveness. Building Research and Information, 36(5), 426-435.

Harty, C. (2008) Implementing innovation in construction: contexts, relative boundedness and actor-network theory. Construction Management and Economics 26(10), 1029-1041.

Howell, G. and Ballard, G. (1999) What is Lean Construction? $7^{\text {th }}$ Conference of the International Group for Lean Construction, Berkeley, California, USA.

Jarzabkowski, P., Balogun, J. and Seidl, D. (2007) 'Strategizing: The Challenge of a Practice Perspective'. Human Relations, 60(1), 5-27.

Jarzabkowski, P. and Spee, A.P. (2009) Strategy-as-practice: A review and future directions for the field. International Journal of Management Reviews, 11(1), 6995. 
Kao, C. Green, S, D. and Larsen, G, D. (2009) Emergent discourses of construction competitiveness: localized learning and embeddedness, Construction Management and Economics, 27(10), 1005-1017.

Koskela, L. (1992) Application of the New Production Philosophy to Construction, Technical Report No. 72, Center for Integrated Facility Engineering, Stanford University, Stanford, CA. Also available online at:

http://www.ce.berkeley.edu/ tommelein/Koskela-TR72.pdf Accessed 12/6/09

Laine, P. and Vaara, E. (2007) Struggling over subjectivity: A discursive analysis of strategic development in an engineering group. Human Relations, 60(1), 29-58.

Latham, M (1994) Constructing the Team, Final Report of the joint Government/Industry Review of Procurement and Contractual Arrangements in the United Kingdom Construction Industry, HMSO.

Latour, B. (2005) Reassembling the social: An introduction to Actor-Network Theory. Oxford, Oxford University Press. 
Leiringer, R. and Green, S, D. and Raja, J, Z. (2009) Living up to the value agenda: the empirical realities of through-life value creation in construction, Construction Management and Economics, 27 (3), 271-285.

Liker, J. (2004) The Toyota Way: 14 Management Principles from the World's Greatest Manufacturer, Maidenhead, McGaw Hill

Ness, K. (2010) The Discourse of 'Respect for People' in UK Construction, Construction Management and Economics, 28(5), 481-493.

Paez, O. Salem, S. Soloman, J. and Genaidy, A. (2005) Moving from Lean Manufacturing to Lean Construction: A Common Sociotechnological Framework, Human Factors and Ergonomics in Manufacturing, 15(2), 233-245.

Rasche, A. and Chia, R. (2009) Researching Strategy Practices: A Genealogical Social Theory Perspective. Organization Studies, 30(7), 713-734.

Sage, D. Dainty, A. and Brookes, N. (2010) Who Reads the Project File? Exploring the power effects of knowledge tools in construction project management, Construction Management and Economics, 28(6), 629-640...... 
Samra-Fredericks, D. (2005) Strategic Practice, 'Discourse' and the Everyday Interactional Constitution of 'Power Effects', Organization, 12(6), 803-841

Seidl, D. (2007) General Strategy Concepts and the Ecology of Strategy

Discourses: A Systemic-Discursive Perspective, Organization Studies, 28(2), 197218.

Styhre, A. (2006) The bureacratization of the project manager function: The case of the construction industry. International Journal of Project Management, 24(3), 271-276.

Van de Ven, A. (2007) Engaged Scholarship: A Guide for Organizational and Social Research, Oxford University Press, Oxford.

Vaara, E. Kleymann, B. and Seristo, H. (2004) Strategies as Discursive Constructions: The Case of Airline Alliances, Journal of Management Studies, 41(1), 1-45.

Watts, J. (2007) Porn, pride and pessimism: experiences of women working in professional construction roles, Work, Employment and Society, 21(2), 299-316. 
Whittington, R. (2006) Completing the Practice Turn in Strategy Research, Organization Studies, 27(5), 613-634.

Wolstenholme, A. (2009) Never Waste a Good Crisis, London, Constructing Excellence, available online at:

http://www.constructingexcellence.org.uk/pdf/Wolstenholme Report Oct 200

9.pdf

Accessed 1/10/10

Womack, J, P. and Jones, D, T. (1996) Lean Thinking, Simon \& Schuster: New York 